\title{
BANANA XANTHOMONAS WILT IN ETHIOPIA: OCCURRENCE AND INSECT VECTOR TRANSMISSION
}

\author{
D. SHIMELASH, T. ALEMU, T. ADDIS ${ }^{1}$, F. L. TURYAGYENDA ${ }^{2}$ \\ and G. BLOMME ${ }^{2}$ \\ Hawassa University, P. O. Box 05, Awassa, Ethiopia \\ ${ }^{1}$ Southern Agricultural Research Institute (SARI), Awassa Agricultural Research Centre, \\ P.O. Box 06, Awassa, Ethiopia \\ ${ }^{2}$ Bioversity International Uganda, P.O. Box 24384, Kampala, Uganda
}

\begin{abstract}
Bacterial wilt caused by Xanthomonas vasicola pv. musacearum (Xvm) is an important disease of enset and banana in south and south-western Ethiopia where, the diversity of the insect fauna on banana inflorescences was unknown and the role of insects as vectors of the disease had not been studied. The objectives of this study were to assess the occurrence of bacterial wilt and male bud infection, the diversity of insect families in banana plantations and the presence of the bacteria on insects collected from diseased inflorescences in south and southwestern Ethiopia. Surveys were carried out and insects were collected from three different zones in 2005. The diversity and richness of the insect families was assessed across sites and genotypes and comparisons were made using the Shannon Diversity Index and the Jack knife estimator, respectively. Correlations were made between the abundance and incidence of insects with the incidence of male bud infection on 'Pisang Awak' plants. A wide range of insect families were recorded and they varied according to banana genotype and altitude. The Drosophilidae and Apinae families were most frequently recorded across sites and genotypes. The 'Wendo' variety (AAA Cavendish group) had the highest diversity and richness of insect families within and across sites. In contrast to the Kembata Tembaro and Bench Maji zones, severe and widespread male bud infection of banana was found in Kaffa, where there was a high diversity of insects on the 'Pisang Awak' and 'Abesha muz' plants. The incidence of male bud infection on 'Pisang Awak' plants was highly correlated with the incidence of insects $\left(\mathrm{R}^{2}=0.964\right)$. The incidence of male bud infection however depends on the floral morphology and altitude. Artificial inoculation with Xvm ooze on fresh male bract and flower scars resulted in infections on 'Pisang Awak' and 'Abesha muz' plants, but the 'Dwarf Cavendish' plants with persistent bracts and flowers remained healthy. Few male bud infections were observed at altitudes above 1,700 masl. Xvm was isolated from Apinae, Lonchaeidae, Muscidae, Tephritidae and Vespidae insect families. Lonchaeidae (Silba spp.) were frequently observed on banana bract and flower scars and could thus be an important insect vector of Xvm in Ethiopia.
\end{abstract}

Key Words: Banana germplasm, insect vectors, male inflorescence infections, wilt intensity, Xanthomonas vasicola pv. musacearum

\section{RÉSUMÉ}

Bactérien flancher causé par Xanthomonas vasicola pv. musacearum) (Xvm) est une maladie importante d'enset et la banane dans la region du Sud et du Sud Est Ethiopienene, la diversité de la faune d'insecte sur les inflorescences de banane était inconnue et le rôle d'insectes comme les vecteurs de la maladie n'était étudiés. Les objectifs de cette étude étaient d'évaluer l'événement de flanche bactérien et l'infection de bourgeon mâle, la diversité de familles d'insecte dans les plantations de banane et la présence des bactéries sur les insectes recueillis des inflorescences malades dans les regions Sud et Sud-Ouest d'Ethiopie. Les enquêtes ont été exécutées et les insectes ont recueilli de trois zones différentes en 2005. La diversité et la richesse des familles d'insecte ont été évaluées à travers les sites et les génotypes et les comparaisons ont fait utilisant l'Indice de Diversité de Shannon et l'estimateur de couteau de Cric, respectivement. Les corrélations ont été faites entre 
l'abondance et l'incidence d'insectes avec l'incidence d'infection de bourgeon mâle sur < Pisang Awak > les plantes. Une grande variété de familles d'insecte a été enregistrée et a été variée selon le génotype de banane et l'altitude. Les familles de Drosophilidae et Apinae étaient le plus fréquemment enregistrées à travers les sites et les génotypes. La variété de « Wendo » (le groupe de Cavendish d’AAA) a eu la plus haute diversité et l’haute richesse de familles d'insecte à travers les sites. Contrairement au Kembata Tembaro et contrairement aux zones de Maji de Banc, l’infection sévère de bourgeons mâles répandue de banane a été trouvée dans Kaffa, où il y avait une haute diversité d'insectes sur les plantes < Pisang Awak > et ( Abesha muz >. L'incidence d'infection de bourgeon sur les plantes mâle < Pisang Awak > ont été extrêmement lié avec l'incidence d'insectes $\left(\mathrm{R}^{2}=0,964\right)$. L'incidence d'infection de bourgeon mâle cependant dépend de la morphologie florale et de l'altitude. L'inoculation artificielle avec Xvm suinte sur la bractée et les cicatrices de fleur mâles frais a pour résultat des infections sur < Pisang Awak > et < Abesha muz > les plantes, mais le < Cavendish Nain > les plantes avec persistantes les bractées et les fleurs restées saines. Peu d’infections mâles de bourgeon ont été observées aux altitudes au-dessus de $1.700 \mathrm{~m}$. Xvm a été isolé d'Apinae, Lonchaeidae, Muscidae, Tephritidae et les familles d'insecte de Vespidae. Lonchaeidae (Silba spp). Été fréquemment observé sur la bractée de banane et les cicatrices de fleur et peut ainsi est un vecteur d'insecte important de Xvm dans Ethiopie.

Mots Clés: Germplasm de banane, les vecteurs d'insecte, les infections d'inflorescence mâles, flanchent l’intensité, Xanthomonas vasicola pv. Musacearum vasicola pv. musacearum

\section{INTRODUCTION}

In Ethiopia, banana is the second major fruit crop after citrus (Gebre Mariam, 1999). All types of bananas are eaten as dessert in Ethiopia. The main banana growing areas are located at Arba Minch, 1,200 metres above sea level (masl) in southern Ethiopia, and in south western Ethiopia along the Kaffa-Bench Maji axis (1,050 - 1,700 masl) (Addis et al., 2004). Throughout the main enset growing areas, and below 2,100 masl, a few banana plants can be found on most enset farms. The total annual banana production in Southern Ethiopia is 190,118 tones (CSA, 2002). However, this production is threatened by among other factors Xanthomonas wilt (XW) caused by Xanthomonas vasicola pv. musacearum (Yirgou and Bradbury, 1968; Ashagari, 1985; Peregrine and Bridge, 1992; Tessera and Quimio, 1994). XW has been endemic to Ethiopia infecting enset and banana for over 50 years and was first reported and described in late 1960's (Yirgou and Bradbury, 1968; 1974). The disease has in recent years spread to Uganda, the Democratic Republic of Congo, Rwanda, Tanzania and Kenya where numerous banana plantations are devastated (CABI, 2003; Tushemereirwe et al., 2003; 2004; Ndungo and Kijana, 2004; Ndungo et al., 2004; Mugenzi et al., 2006: Ndungo et al., 2006). Yield losses of up to $70 \%$ have been reported in beer banana (ABB group) dominated plantations in central Uganda (Karamura et al., 2006). Disease spread on banana mainly occurs through the use of contaminated farm tools and with insect vectors which visit male bract and flower scars (EdenGreen, 2004).

Xanthomonas vasicola pv. musacearum is widely spread especially in South and SouthWestern Ethiopia where enset and banana are commonly grown (Yirgou and Bradbury, 1968, 1974; Ashagari, 1985; Addis et al., 2004). Although the epidemiology of XW has not been systematically studied in Ethiopia, there is evidence that infection by Xvm occurs via inflorescences and that the disease is transmitted by insects under field conditions (Eden-Green, 2004; Tinzaara et al., 2006). However, little information is available in Ethiopia with regards to insect diversity and their role as potential vectors for Xvm on banana. Such information is vital to establish an integrated management strategy against XW. The objectives of this study were, therefore to assess the occurrence of bacterial wilt and male bud infection, the diversity of insect families in banana plantations and the presence of bacteria on insects collected from diseased inflorescences in South and SouthWestern Ethiopia. 
MATERIALS AND METHODS

Description of the study sites, Musa genotypes grown and $\mathrm{XW}$ incidence. On farm assessments of banana genotypes grown, XW presence and insect vector transmission work was carried out in the Southern Nations Nationalities Peoples Region (SNNPR) of Ethiopia. The whole SNNPR has a total area of about $118,000 \mathrm{~km}^{2}$ accounting for $10 \%$ of the total area of the country. The region is divided into 12 zones having 72 districts and five special districts based on ethnicity and language. The zones found in this region are: Bench Maji, Dawro, Gedeo, Gurage, Hadyia, Kaffa, Kembata Tembaro (KT), North Omo, Shaka, Sidama, South Omo, and Wolyita. The southern region of Ethiopia lies between $4^{\circ} 27^{\prime}$ and $8^{\circ} 30^{\prime}$ latitude North and $34^{\circ} 21^{\prime}$ and $39^{\circ} 11^{\prime}$ longitude East. The elevation in the region ranges from 376 to 4,207 masl with the lowest elevation found near Lake Turkana in South Omo zone and the highest peak on mount Guge in North Omo.

The study was conducted between $1^{\text {st }}$ June and $18^{\text {th }}$ November 2005 at three different zones namely, Bench Maji (1,350 - 1,750 masl), Kaffa (1,350 - 1,750 masl) and Kembata Tembaro (1,800 - 2,100 masl). In the Bench Maji and Kaffa zones, one representative district i.e., Bench and Gimbo respectively, were selected. Two representative districts namely, Kachabirra (1,800-1,900 masl) and Kadidagamella (>2000 masl) were selected in Kembata Tembaro. At Bench Maji, 15 farms were assessed from 3 peasant associations (1,3501,700 masl), while 11 farms were assessed from 5 peasant associations in Kaffa (1,600-1,750 masl). The first surveyed distict in Kembata Tembaro was Kachabirra where 5 farms were assessed (1806-1885 masl), while in the second Woreda Kadidagamella 3 farms (2,090-2,100 masl) were assessed. Thirty plants per genotype present at a site and across all farms in a site were assessed for XW based on visible disease symptoms (Tushemereirwe et al., 2003). The incidence of male bud infection was also recorded.

Insect collection and identification. At each of the three zones, insects were collected from the female and male flowers of 30 plants per genotype using a cotton bag. Insects which were considered morphologically similar were sorted, counted, labelled and put in vials containing 95\% alcohol. Further sorting of insects was continued using a stereomicroscope (10-250X) at the Crop Protection Laboratory of the Hawassa University, Awassa, Ethiopia. The insects were then identified to family level at the Entomology Laboratory, Department of Biology, Addis Ababa University, Ethiopia. Further identification of insects to the genus and in some cases to species level was carried out at the National Museum, Wales, UK. Voucher specimens were deposited at the Crop Protection Laboratory of the University of Hawassa. Different insect guilds including sap feeders, pollinators, herbivores and predators were recorded.

Insect diversity and richness. The insect richness was estimated using the incidence based on first-order Jack knife estimator (Burnham and Overtone 1978, 1979; Heltshe and Forrester, 1983). Family-level diversity was calculated for each genotype per site using the Shannon diversity index. The richness estimators and diversity index were calculated with Estimates (Coldwell, 2005). One way ANOVA was used to determine the variation in Richness estimates and diversity indices for each genotype, within and across sites and at different altitudes using the GenStat for Windows statistical package (Genstat, 2003). Means were separated and compared using the 95\% confidence interval derived from Tukey.

The relationship between $X v m$ male bud infection and insect incidence/abundance. This study was conducted at the "Kajaraba" peasant association (1,600 masl) in the Kaffa zone where male bud infection was widespread. The collection of insects and the assessment of wilt incidence were done monthly for five consecutive months starting from June 2005. During each month fifty 'Pisang Awak' plants whether diseased or healthy with a complete inflorescence were randomly selected. Insects were collected from the male inflorescences using a cotton bag. The evaluation of wilt incidence was carried out based on male inflorescence symptoms as described by Tushemereirwe et al. (2003). The wilt intensity was calculated monthly as the proportion of plants with an inflorescence infection. Correlations between abundance of 
insects and wilt intensity were made using the GenStat for Windows statistical package (Genstat, 2003).

\section{Artificial inoculation of $X v m$ on banana flower and bract scars. This study was conducted at Bonga, Kaffa zone on farmers' fields at an altitude of 1,800 masl. There was no Xvm in this area prior to the trial. For each of the three genotypes namely, 'Pisang Awak', 'Abesha muz', and 'Dwarf Cavendish', ten flowering plants were used. The oldest set of male flowers and corresponding bract of the 'Pisang Awak' and 'Abesha muz' plants were gently removed and bacterial ooze obtained from a freshly cut infected pseudostem was smeared on the bract scars and moist cushions of the male flowers. 'Dwarf Cavendish' is a variety which has persistent bracts and flowers. For this variety, parts of the old dried neutral/male flowers were gently removed and bacterial ooze was smeared on the tiny underdeveloped fruits which became visible. All treated inflorescences were subsequently covered with a woven plastic bag until the study ended. Xvm infections were assessed 45 days after inoculation. In case a flower infection was observed, true stem/ pseudostem sections were cut to verify the presence of bacterial ooze.}

\section{EVALUATION OF INSECTS AS POTENTIAL VECTORS OF XVM}

Collection of insects. Insects were collected from diseased male inflorescences of 'Pisang Awak' plants grown at Bonga, Kaffa zone. The insects were collected using a cotton bag with a glass jar attached to the terminal side. The bags were used to envelop the male flower. Sixty insects were sampled from the following families: Apinae, Drosophilidae, Lonchaeidae, Tephritidae, Muscidae and Vespidae.

Culture media and $X v m$ isolation. Immediately after collection of the insects, the isolation of $X v m$ from the insect's bodies was carried out at the Veterinary Laboratory in Mizan Tefferi, Bench Maji zone. A selective media was used for Xvm isolation (Schaad and Stall, 1988). Yeast extract Peptone Glucose Agar (YPGA) suspended in one litre distilled water with a pH of 7.4 was prepared.
The media were poured out aseptically into sterile petri-dishes having a diameter of $10 \mathrm{~cm}$ and kept under sterile conditions. The insects collected from male inflorescences were grouped into two groups. The first group consisted of 10 insects which were deliberately contaminated by dipping them in fresh Xvm ooze collected from infected field grown plants. These insects were subsequently washed with diluted liquid media. These insects were labelled as Treated Check Insects (TCI). The second group of insects consisting of 50 insects, labelled as Field Collected Insects (FCI), were left untreated. These insects were also washed with diluted liquid media. From each suspension a sub sample of $10 \mathrm{ml}$ was mixed with $100 \mathrm{ml}$ diluted liquid media. The liquid media was then shaken for 10 minutes at $300 \mathrm{rpm}$ using a shaker. A loopful of the suspension was streaked on YPGA plates and replicated five times per insect species and group. $X v m$ was also isolated from an infected banana plant. This Xvm ooze was also diluted in the liquid media and streaked on YPGA plates in five replications. The plates were incubated at $28^{\circ} \mathrm{C}$ for 48-72 hours according to Schaad and Stall (1988). The TCI and Infected Plant Part (IPP) were used as a positive control in order to check the similarity of the bacterial wilt colonies. The Xvm was further identified based on colony morphology descriptions established by Wardlaw (1972). Pure colonies were transferred to fresh YPGA slants incubated at $28^{\circ} \mathrm{C}$ for 72 hours and preserved at $4^{\circ} \mathrm{C}$ at Awassa, Ethiopia for further experimental work.

\section{RESULTS AND DISCUSSION}

Musa genotypes grown and XW incidence. The banana genotypes 'Pisang Awak' (ABB genome) (Pillay et al., 2006), 'Abesha muz' (highland AAA), 'Uganda red' (AAA), 'Dwarf Cavendish' (AAA), 'Melkasedi' (AAA Cavendish group), 'Wendo' (AAA Cavendish group) and 'Italy' (AAB) are cultivated in Kembata Tembaro. 'Pisang Awak' and 'Abesha muz' are commonly grown in the Kaffa area, while 'Dwarf Cavendish' is the predominant genotype in Bench Maji.

The incidence of XW varied across the study sites $(P=0.05)$. In Kaffa, bacterial wilt was widespread and male bud infections were 
commonly observed on 'Pisang Awak' and to a lesser extent on 'Abesha muz' grown at 1,600 masl. The first report of banana wilt from Kaffa, SouthWestern Ethiopia indicated that the cultivar 'Du Casse' was highly susceptible to Xvm (Yirgou and Bradbury, 1974). 'Du Casse' or 'Ducasse' is a synonym for 'Pisang Awak' and 'Kayinja' (ABB) (Jones, 2000). XW was also observed in Kembata Tembaro ( $>1,800$ masl) but no male bud infections were recorded. On the other hand, no bacterial wilt was observed in Bench Maji where 'Dwarf Cavendish' a variety with persistent male bracts and flowers is predominant. The survey also revealed a decrease in male bud infection with increasing altitude in sites where 'Pisang Awak' and 'Abesha muz' are commonly grown (Fig. 1). Very few male bud infections were observed in areas above 1,700 masl. Addis et al. (2004) also reported that male bud infection was common on 'Pisang Awak' mats in areas below 1,700 masl. This observation is in agreement with what was reported in Masisi (mainly > 1,700 masl) in the eastern part of the Democratic Republic of Congo where $90 \%$ of bananas are 'Pisang Awak' and where very few male bud infections are observed (Ndungo et al., 2004). The absence of insect vector transmission and hence male bud infections may prevent a fast spread of the disease in areas above 1,700 masl. However, transmission with contaminated farm tools remain the main mode of XW spread in such areas.

\section{Diversity and abundance of insect species on} banana and their relationship with XW intensity. A total of 4,695 insects were collected from the three study sites. The collected insects belonged to 5 orders and 17 families (Table 1). The highest proportion of insects were in the order Diptera (88.6\%) followed by Hymenoptera (6\%) (Table 2 ). The most common insect families were the Drosophilidae and the Apinae (Table 2). The highest mean number of insects were recorded on 'Dwarf Cavendish' and 'Wendo' plants, while the lowest numbers were found on 'Italy' and 'Uganda red' plants (Table 3).

The incidence of male bud infection and XW was observed to be higher in lower altitudes (Fig. 1). Across the three study sites, family level richness and diversity differed significantly $(p<0.001)$. Family level richness and diversity were highest in Bench Maji, intermediate in Kaffa and lowest in Kembata Tembaro (Fig. 2). 'Dwarf Cavendish' had the lowest family level diversity in Kembata Tembaro. Higher diversity and richness in insect families was observed at lower elevations compared to higher elevations (Fig.

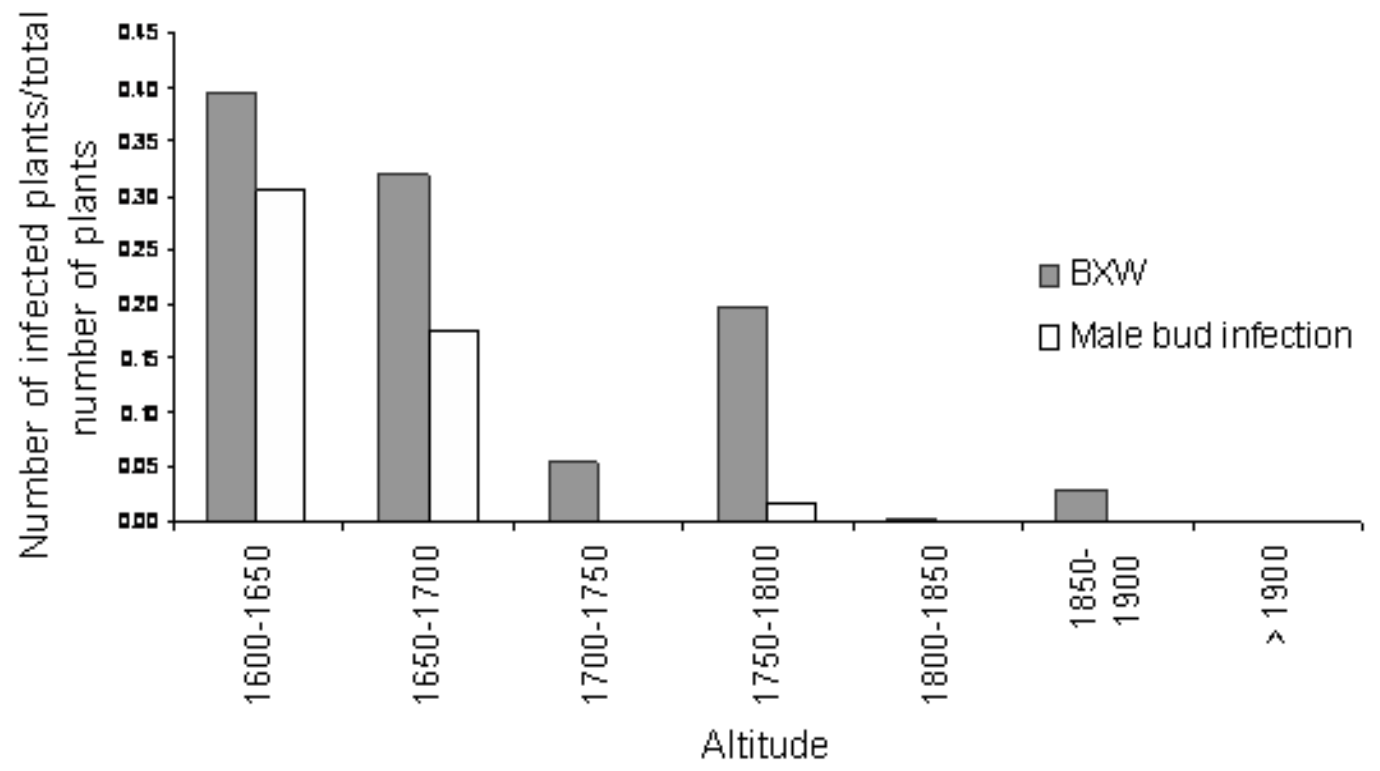

Figure 1. The relationship between altitude and the incidence of male bud infection and banana Xanthomonas wilt. 
TABLE 1. Insect families and species collected from banana flowers across three study areas in Ethiopia

\begin{tabular}{|c|c|c|c|}
\hline Common name & Order & Family/subfamily & Species name \\
\hline Bee & Hymenoptera & Apinae & Apis sp. \\
\hline Fly & Diptera & Drosophilidae & $\begin{array}{l}\text { Zaprionus vittiger Coguillet } \\
\text { Z. tuberculata Malloch } \\
\text { Drosophila sp. } \\
\text { Leucophenga sp. }\end{array}$ \\
\hline Fly & Diptera & Drosophilidae & Drosophila sp. \\
\hline Fly & Diptera & Lonchaeidae & Silba sp. \\
\hline Butterfly & Lepidoptera & * & butterfly \\
\hline Wasp & Hymenoptera & Formicidae & * \\
\hline Bug & Hemiptera & Heteroptera/ Lygaeidae) & * \\
\hline Stink Bug & Hemiptera & Heteroptera/Scutellaridae) & $*$ \\
\hline Fruit Fly & Diptera & Tephritidae & Ceratitis (Pterandrus) rosa Karsch \\
\hline Fly & Diptera & Muscidae & Neomyia rudissima (Loew) \\
\hline Beetle & Coleoptera & Staphylinidae & * \\
\hline Beetle & Coleoptera & Tenebrionidae & * \\
\hline Beetle & Coleoptera & Nitidulidae & * \\
\hline Beetle & Coleoptera & Staphylinidae & * \\
\hline Bee & Hymenoptera & Apinae & Apis sp. \\
\hline Bug & Hemiptera & Heteroptera/Pyrrocoridae) & * \\
\hline Fly & Diptera & Muscidae & Musca sp. \\
\hline Wasp & Hymenoptera & Vespidae & * \\
\hline Wasp & Hymenoptera & * & * \\
\hline Fly & Diptera & Neriidae & Chaetonerius sp. \\
\hline Beetle & Coleoptera & Nitidulidae & Carpophilus sp. \\
\hline Fly & Diptera & Sarcophagidae & Sarcophaga sp. \\
\hline Beetle & Coleoptera & Curculionidae & Phanerognathasp. \\
\hline Wasp & Hymenoptera & Formicidae & * \\
\hline
\end{tabular}

* Unidentified families or species

3). Family level diversity and richness also differed according to genotype (Fig. 4). The lowest insect family richness and diversity was recorded from the genotype 'Italy' while 'Wendo' showed the highest insect family richness and diversity. In Kaffa where 'Pisang Awak' and 'Abesha muz' are the main genotypes, family level richness and diversity were higher on 'Pisang Awak' than on 'Abesha muz' (Fig. 5). Nectar feeding insects were more commonly observed than sap feeders and predators (Table 4). Large numbers of Lonchaeidae were observed feeding on sap oozing from bract scars in Kaffa (Table 5). Nectar feeders were from the families Drosophilidae, Tephritidae, Apinae and Vespidae (Table 5).

The relationship between male bud infection and insect incidence/abundance. There was a significant correlation between wilt intensity (male bud infection) and incidence of insects on 'Pisang Awak' in Kaffa $\left(\mathrm{R}^{2}=0.964\right)$. Similarly, there was a significant correlation $\left(\mathrm{R}^{2}=0.77\right)$ between the abundance of insect species and wilt intensity. The high correlation between wilt intensity and incidence, on one hand and abundance of insects on the other, indicates the possible involvement of insects in the transmission of XW.

Artificial inoculation of Xvm on banana flower and male bract scars. Both artificially inoculated 'Pisang Awak' and 'Abesha muz' plants showed $100 \%$ wilt symptoms 45 days after inoculation. Bacterial ooze and discolourations were observed only in the true stem/flower stalk of the infected plants indicating a true inflorescence infection. 


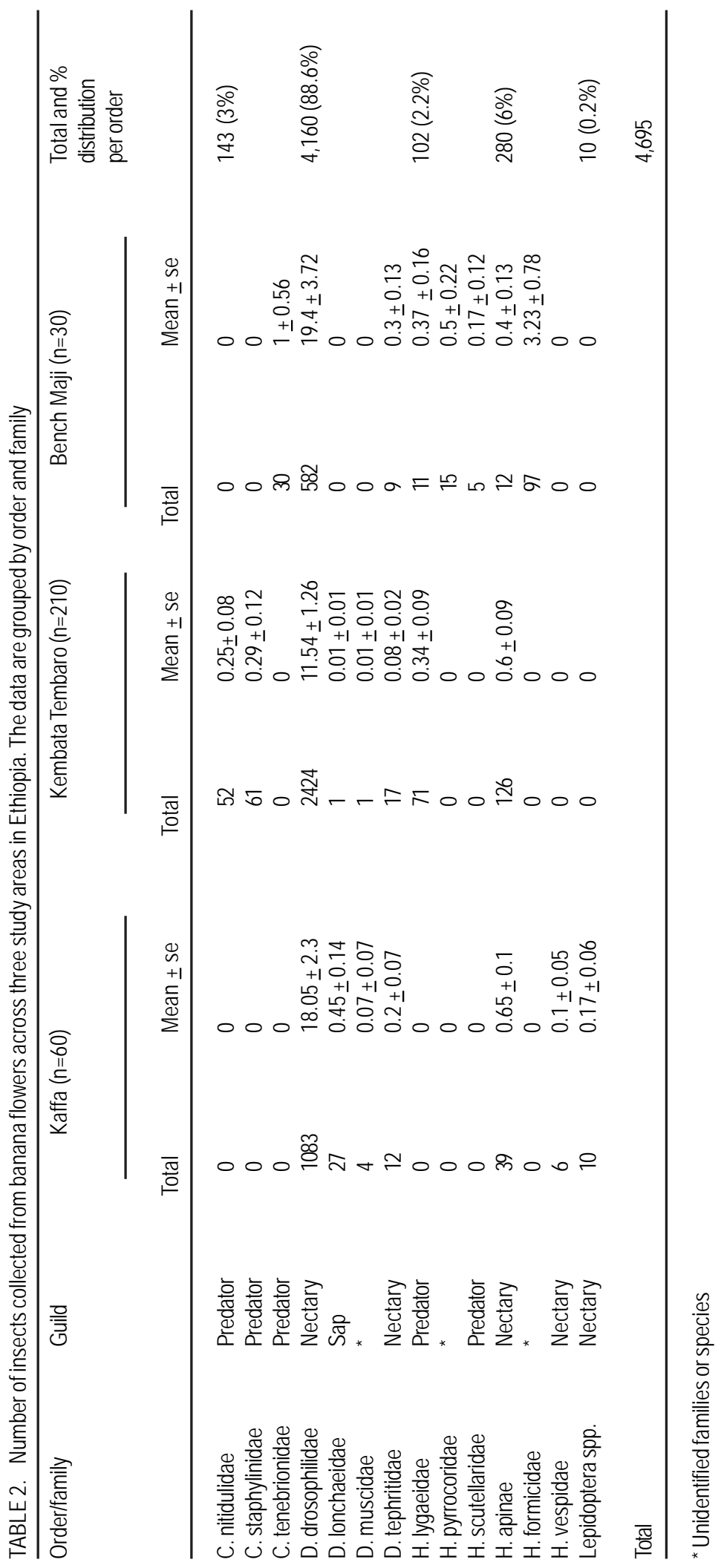




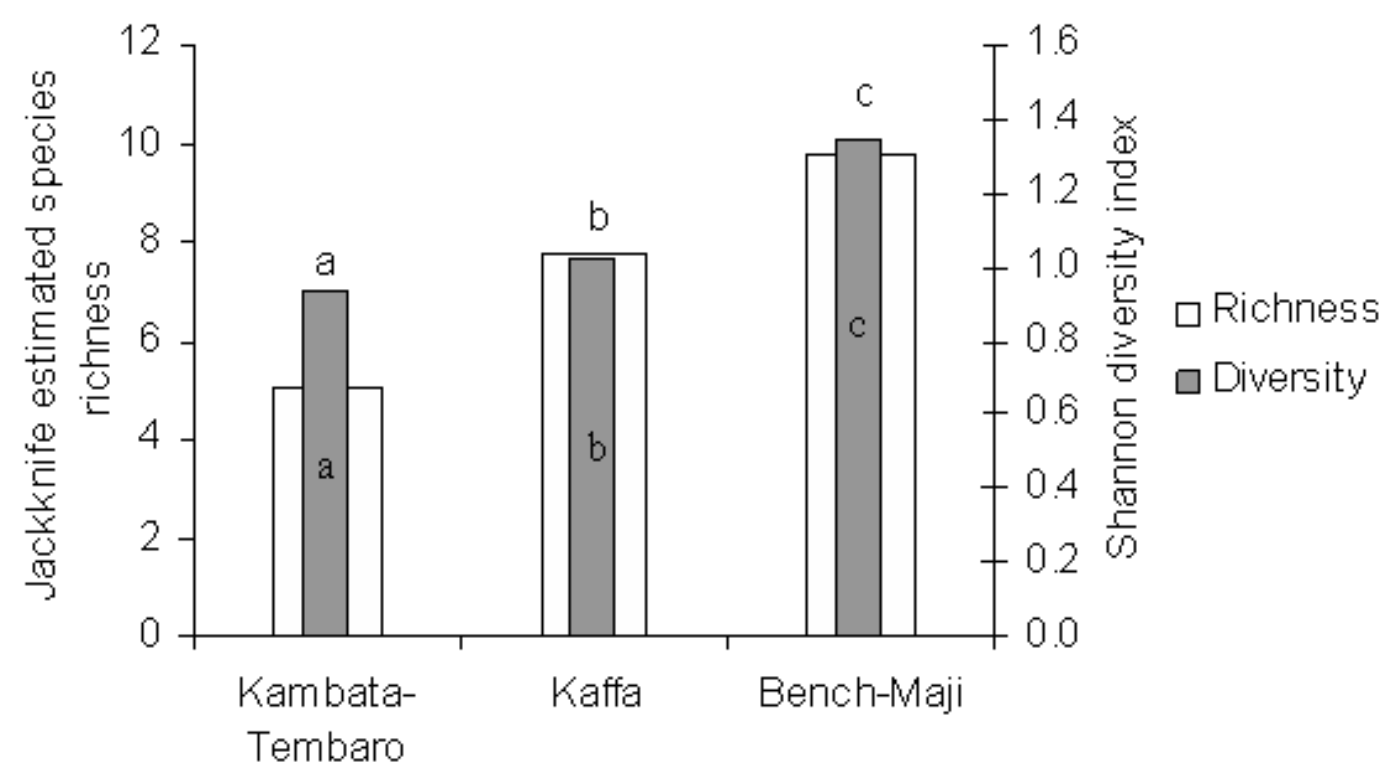

Figure 2. Mean family level richness (Jackknife estimated richness) and diversity (Shannon diversity index) of insects visiting banana flowers at each study site. Bars with the same letter are not significantly different at $P<0.05$ according to Tukey's studentised range test.

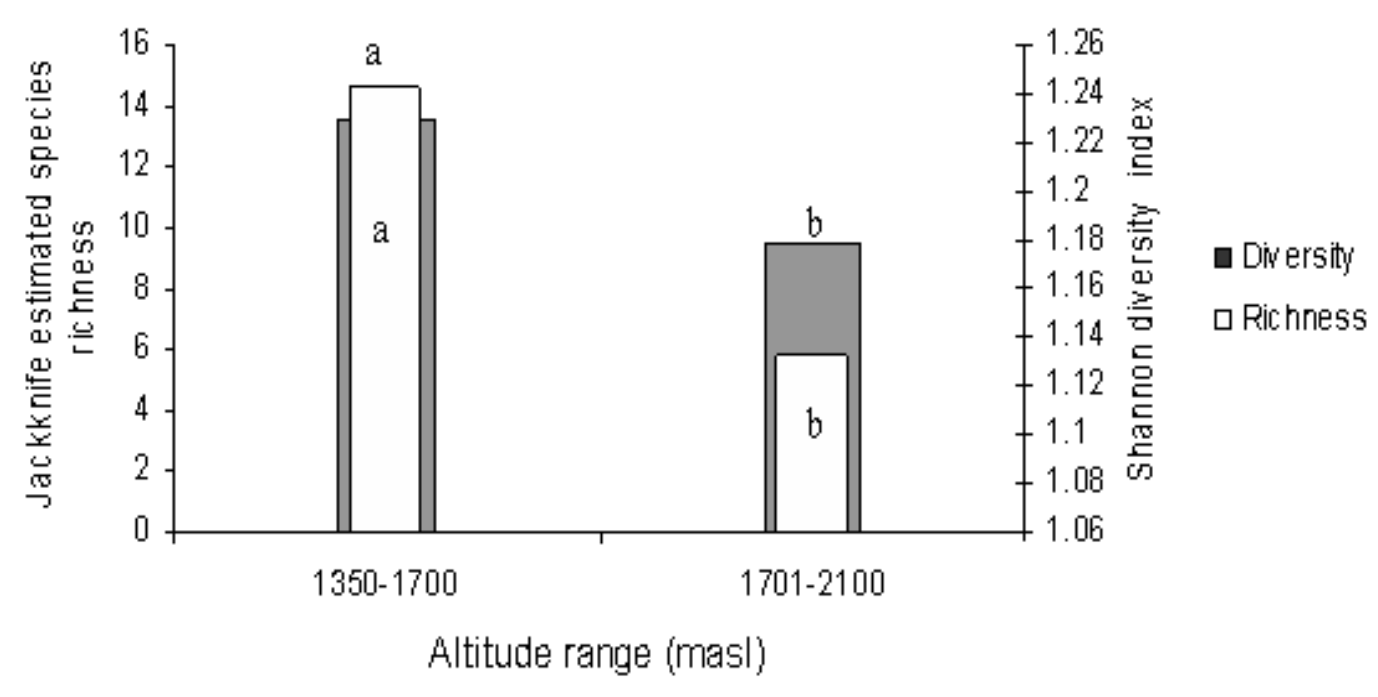

Figure 3. Mean family level richness (Jackknife estimated richness) and diversity (Shannon diversity index) of insects visiting banana flowers in relation to altitude. Bars with the same letter are not significantly different at $P<0.05$ according to Tukey's studentised range test.

On the other hand, the 'Dwarf Cavendish' plants showed no wilt symptoms. Neither ooze nor discolourations were observed in the true stem and fruits of the 'Dwarf Cavendish' plants. The absence of infections on the 'Dwarf Cavendish' plants may be due to the flower and bract morphology. Silba sp. was frequently found feeding on sap from the male cushions of 'Pisang 


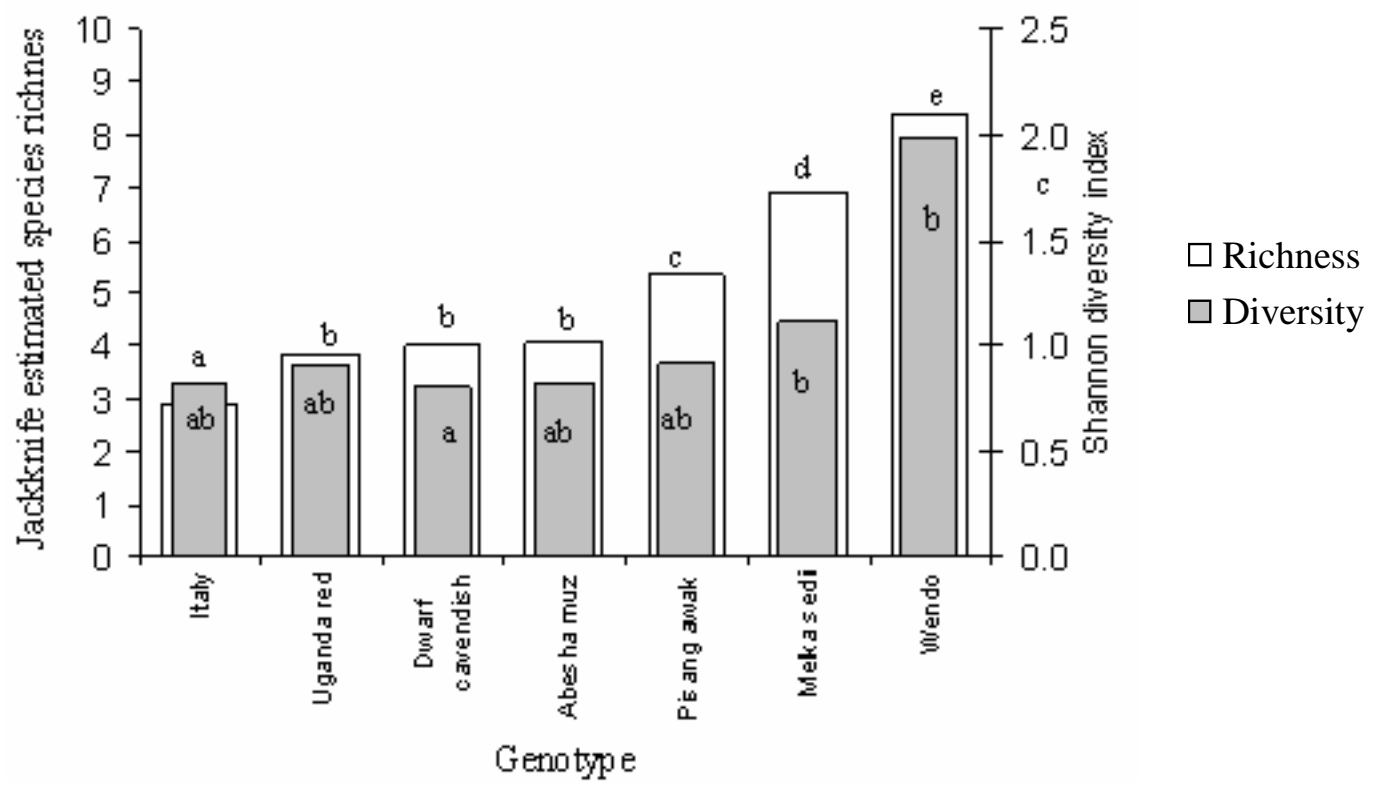

Figure 4. Mean family level richness (Jackknife estimated richness) and diversity (Shannon diversity index) of insects visiting different banana genotypes in Kembata Tembaro, Ethiopia. Bars with the same letter are not significantly different at $\mathrm{P}<0.05$ according to Tukey's studentised range test.

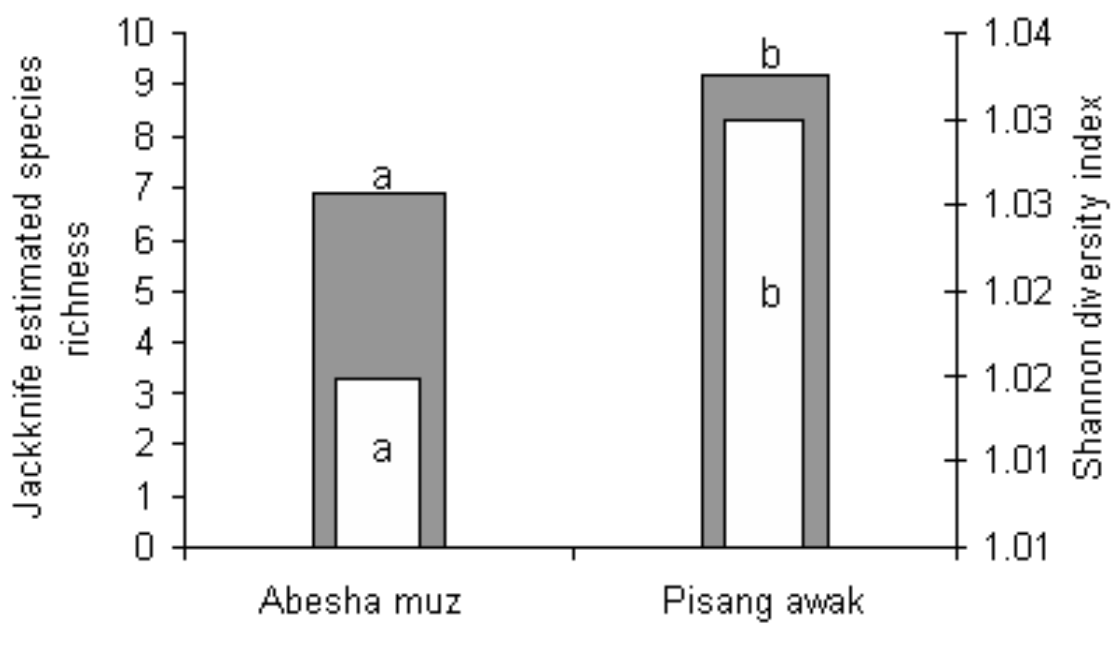

Banana genotypes

Figure 5. Mean family level richness and diversity of insects collected from flowers of 'Abesha muz' and 'Pisang Awak' in Kaffa, Ethiopia. Bars with the same letter are not significantly different at $\mathrm{P}<0.05$ according to Tukey's studentised range test.

Awak' and 'Abesha muz' plants in Kaffa, where the incidence of male bud infection was severe. Earlier on, Tinzaara et al. (2006) reported that insects transmit the disease from sick to healthy plants as they feed on sap oozing from wounds on the inflorescences. Xvm easily ooze out of infected inflorescences whenever there is a wound. Insects most likely pick up bacteria from these wounds during feeding (Tushemereirwe $e t$ al., 2003). Buddenhagen and Elsasser (1962) reported that insect vector transmission in banana occurs when bacterial ooze is carried by 
TABLE 3. Number of insects collected from different banana genotypes in Ethiopia

\begin{tabular}{lcccc}
\hline Genotype & Genome group & Number of plants & Total number of insects & $\begin{array}{c}\text { Mean number of insects } \\
\text { per plant +/- se }\end{array}$ \\
\hline Abesha muz & AAA & 60 & 588 & $9.80 \pm 1.85$ \\
Dwarf Cavendish & AAA & 60 & 1393 & $23.22 \pm 2.44$ \\
Italy & AAB & 30 & 51 & $1.70 \pm 0.42$ \\
Melkasedi & AAB & 30 & 565 & $18.83 \pm 3.65$ \\
Pisang Awak & ABB & 60 & 1064 & $17.73 \pm 2.35$ \\
Uganda red & AAA & 30 & 56 & $1.87 \pm 0.65$ \\
Wendo & AAA & 30 & 978 & $32.60 \pm 5.19$ \\
Total & & 300 & 4,695 & $15.65 \pm 1.13$ \\
\hline
\end{tabular}

TABLE 4. Frequency of occurrence of insects on banana flowers in three study sites in Ethiopia

\begin{tabular}{llccc}
\hline Common name & Family/subfamily & Kaffa $(\mathrm{n}=60)$ & Kembata Tembaro $(\mathrm{n}=210)$ & Bench Maji $(\mathrm{n}=30)$ \\
\hline Bee & Apinae & 26 & 50 & 3 \\
Fly & Drosophilidae & 32 & 78 & 14 \\
Fly & Drosophilidae & 29 & 60 & 16 \\
Fly & Lonchaeidae & 11 & 1 & 0 \\
Butterfly & * & 7 & 0 & 0 \\
Wasp & Formicidae & 0 & 0 & 14 \\
Beetle & Lygaeidae & 0 & 18 & 5 \\
Stink Bug & Scutellaridae & 0 & 0 & 2 \\
Fruit Fly & Tephritidae & 7 & 14 & 5 \\
Fly & Muscidae & 1 & 0 & 0 \\
Beetle & Staphylinidae & 0 & 7 & 0 \\
Beetle & Tenebrionidae & 0 & 0 & 4 \\
Beetle & Nitidulidae & 0 & 9 & 0 \\
Bee & Apinae & 5 & 13 & 5 \\
Bug & Pyrrocoridae & 0 & 0 & 5 \\
Fly & Muscidae & 0 & 1 & 0 \\
Wasp & Vespidae & 5 & 0 & 0 \\
\hline
\end{tabular}

* Unidentified family/subfamily

insects from infected peduncles to the moist cushions on the peduncle of a healthy plant.

Evaluation of insects as potential vectors of $X v \mathrm{vm}$. $X v m$ colonies were isolated from Apinae, Lonchaeidae, Muscidae, Tephritidae and Vespidae insect families (Table 6). These colonies had characteristics of Xanthomonas vasicola pv. musacearum. During the second round of isolations $\mathrm{Xvm}$ colonies were only detected on the family Apinae (Table 6). In Honduras, bees and wasps were found to carry Ralstonia solanacearum in Bluggoe plantations (Buddenhagen and Elsasser, 1962). In Uganda, stingless bees and grass flies are suspected agents of Xvm (Tinzaara et al., 2006).

\section{CONCLUSIONS}

There was a wide range of insect families in smallscale banana plantations in south and southwestern Ethiopia and their diversity varied with banana genotype and altitude. A higher insect diversity was found at lower altitudes and 'Dwarf 
TABLE 5. Insects visiting the male or female flowers of 'Pisang Awak' plants at Kembata Tembaro and Kaffa. Only the most likely insect vectors are included in this Table

\begin{tabular}{|c|c|c|c|c|c|c|c|}
\hline \multirow{4}{*}{$\begin{array}{l}\text { Common } \\
\text { name }\end{array}$} & \multirow{4}{*}{$\begin{array}{l}\text { Familyl } \\
\text { subfamily }\end{array}$} & \multicolumn{6}{|c|}{ Study area } \\
\hline & & \multicolumn{2}{|c|}{ Kembata Tembaro } & \multicolumn{4}{|c|}{ Kaffa } \\
\hline & & \multirow[t]{2}{*}{ Female } & \multirow[t]{2}{*}{ Male } & \multirow[t]{2}{*}{ Female } & \multicolumn{3}{|c|}{ Male } \\
\hline & & & & & Bract scars & Flower scars & Nectar \\
\hline Bee & Apinae & $x$ & $X$ & $X$ & & & $X$ \\
\hline Fly & Drosophilidae & $x$ & $x$ & $x$ & & $x$ & $x$ \\
\hline Fly & Drosophilidae & $x$ & $x$ & $x$ & & $x$ & $x$ \\
\hline Fly & Lonchaeidae & & & $x$ & $x$ & $x$ & \\
\hline Wasp & Formicidae & & & $x$ & & & \\
\hline Fruit fly & Tephritidae & $x$ & $x$ & $X$ & & $x$ & $x$ \\
\hline Fly & Muscidae & & & $x$ & & & \\
\hline Bee & Apinae & $x$ & $x$ & $x$ & & & $x$ \\
\hline Fly & Muscidae & $x$ & & & & & \\
\hline Wasp & Vespidae & & & $x$ & & $x$ & $x$ \\
\hline
\end{tabular}

TABLE 6. Isolation of Xvm from different insects, collected from infected banana male inflorescences in Kaffa, Ethiopia

\begin{tabular}{|c|c|c|c|c|c|}
\hline \multirow[t]{2}{*}{ Order } & \multirow[t]{2}{*}{ Family } & \multicolumn{2}{|c|}{$1^{\text {st }}$ trip } & \multicolumn{2}{|c|}{$2^{\text {nd }}$ trip } \\
\hline & & $X v m^{*}$ & $X v m^{\star \star}$ & $X v m^{*}$ & $X v m^{\star \star}$ \\
\hline Hymenoptera & Apinae & + & + & + & + \\
\hline Diptera & Drosophilidae & - & + & & \\
\hline Diptera & Drosophilidae & - & + & - & + \\
\hline Diptera & Lonchaeidae & + & + & & \\
\hline Diptera & Tephritidae & + & + & - & + \\
\hline Diptera & Muscidae & + & + & - & + \\
\hline Hymenoptera & Vespidae & + & + & - & + \\
\hline
\end{tabular}

$+=X v m$ detected

- = not detected

${ }^{*} \mathrm{FCl}=$ field collected insects

${ }^{*} \mathrm{TCl}=$ artificially contaminated insects

Cavendish' hosted the highest diversity of insect families compared to the other banana genotypes studied. The Drosophilidae and Apinae families were most frequently recorded across sites and genotypes. The incidence of male bud infection on 'Pisang Awak' plants was highly correlated with the incidence of insects suggesting that insects could play a pivotal role in XW transmission through feeding on inflorescences. The incidence of male bud infection however depends on the flower morphology and the altitude. Plants with persistent male bracts and flowers may escape male bud infection due to the absence of flower and male bud scars/wounds on the peduncle. Male bud infections reduced with an increase in altitude. Bacteria were isolated 
from insects collected from diseased plants. Hence, insects could be vectors of XW.

\section{ACKNOWLEDGMENTS}

The authors would like to thank the Flemish Association for Development Co-operation and Technical Assistance (VVOB) for its financial assistance. We would also like to thank Dr. Bekele Jembere from the University of Addis Ababa, Ethiopia and Dr. Mike Wilson from the National Museum Wales, UK for identifying the insects. Dr. Simon Eden-Green is also thanked for providing research ideas and constructive comments during the study.

\section{REFERENCES}

Addis, T., Handoro, F. and Blomme, G. 2004. Bacterial Wilt (Xanthomonas campestris pv. musacearum) on Enset and Banana in Ethiopia. InfoMusa 13(2): 44-45.

Ashagari, D. 1985. Studies on the bacterial wilt of Enset (Ensete ventricosum) and prospects for its control. Ethiopian Journal of Agricultural Science 7(1):1-14.

Buddenhagen, I.W. and Elsasser, T.A. 1962. An insect spread bacterial wilt epiphytotic of Bluggoe Banana. Nature 194(4824): 164-165.

Burnham, K.P. and Overton, W.S. 1978. Estimation of the size of a closed population when capture probabilities vary among animals. Biometrika 65: 623-633.

Burnham, K.P. and Overton, W.S. 1979. Robust estimation of population size when capture probabilities vary among animals. Ecology 60 : 927-936.

CABI, 2003. New disease threatens East Africa banana production. News Release. CABI

Coldwell, R. K. 2005. EstimateS: statistical estimation of species richness and shared species from samples. Version7.5. Users guide and application http://purl.oclc.org/ estimates).

CSA (Central Statistical Authority). 2002. Ethiopian agricultural sample enumeration, 2001/02. Results for Southern Nations Nationalities and Peoples Region. Statistical report on area and production of crops. Addis
Ababa, Ethiopia, CTR Publications. pp. 101102.

Eden-Green, S. 2004. How can the advance of banana Xanthomonas wilt be halted? InfoMusa 13(2): 38-41.

Gebere Mariam, S. 1999. Banana production and utilization in Ethiopia. Research Report. No. 35. Ethiopian Agricultural Research Organization, Ethiopia. p. 48.

Genstat, 2003. VSN International. Genstat Seventh Edition. Lawes Agricultural Trust.

Heltshe, J. and Forrester, N.E. 1983. Estimating species richness using the jackknife procedure. Biometrics 39: 1-11.

Jones, R.D. 2000. Introduction to banana, abaca and enset. In: Jones D.R. (ed.). Diseases of Banana, Abaca and Enset. CABI Publishing. Wallingford, Oxon, UK. pp. 1-36.

Karamura, E., Kayobyo, G. Blomme, G., Benin, S., Eden-Green, S.J. and Markham, R. 2006. Impacts of XW epidemic on the livelihoods of rural communities in Uganda. In: Saddler, G., Elphinstone, J. and Smith, J. (Eds.), p. 57. Programme and Abstract Book of the $4^{\text {th }}$ International Bacterial Wilt Symposium, $17^{\text {th }}-20^{\text {th }}$ July 2006, The Lakeland Conference Centre, Central Science laboratory, York, UK. Mgenzi, S.R.B., Muchunguzi, D., Mutagwaba, T., Mkondo, F., Mohamed, R. and Aritua, V. 2006. An out break of Banana Bacterial wilt disease in Muleba District, Kagera Region, Tanzania. African Crops Net. http:// www.africancrops.net/news/april06.

Ndungo, V. and Kijana, R. 2004. Diagnostic et stratégies pour la lutte durable contre la maladie des bananiers et bananier plantain dans la collectivité des Bashali, Territoire de Masisi, Province du Nord-Kivu, DRC, Goma, 26-29 January 2004. p. 21.

Ndungo V., Bakelana, K., Eden-Green, S. and Blomme, G. 2004. An outbreak of banana Xanthomonas wilt (Xanthomonas campestris pv. musacearum) in the Democratic Republic of Congo. InfoMusa 13(2):43-44.

Ndungo, V., Eden-Green, S., Blomme, G., Crozier, J. and Smith, J. 2006. Presence of banana Xanthomonas wilt (Xanthomonas campestris pv. musacearum) in the Democratic Republic of Congo (DRC). Plant Pathology New Disease Reports 55(2): 294. 
Peregrine, W.T.H. Bridge. 1992. The lesion nematode Pratylenchus goodeyi, an important pest of Ensete in Ethiopia. Tropical Pest Management 38:325-326.

Pillay, M., Ogundiwin, E., Tenkouano, A. and Dolezel, J. 2006. Ploidy and genome composition of Musa germplasm at the International Institute of Tropical Agriculture (IITA). African Journal of Biotechnology. 5(13): 1224-1232.

Schaad, N.W. and R.E. Stall. 1988. Xanthomonas. In N.W. Schaad (Ed.), pp. 81-84. Laboratory guide for identification of plant pathogenic bacteria. 2nd Edition. APS Press. St. Paul, Minnesota.

Tessera, M. and Quimio, A.J. 1994. Research on enset pathology. In: Edward H, and Lemma D (Eds), pp. 217-225. Proceedings of the second national horticultural workshop of Ethiopia, Addis Ababa, Ethiopia, 1-3 December, 1992.

Tinzaara, W., Gold, C.S., Ssekiwoko, F., Tushemereirwe, W., Bandyopadhyay, R. and Eden-Green, S. J. 2006. The possible role of insects in the transmission of banana Xanthomonas wilt. In: Saddler, G., Elphinstone, J. and Smith, J. (Eds.), 60pp.
Programme and Abstract Book of the $4^{\text {th }}$ International Bacterial Wilt Symposium, $17^{\text {th }}-20^{\text {th }}$ July 2006., The Lakelana Conference Centre, Central Science Laboratory, York, UK.

Tushemereirwe, W., Kangire, A., Smith, J., Ssekiwoko, F., Nakyanzi, M., Kataama, D., Musiitwa, C. and Karyeija, R. 2003. An outbreak of bacterial wilt on banana in Uganda. InfoMusa 13(2): 44-5.

Tushemereirwe, W., Kangire, A., Ssekiwoko, F., Offord, L.C., Crozier, J., Boa, E., Rutherford, M. and Smith, J.J. 2004. First report of Xanthomonas campestris pv. musacearum on banana in Uganda. Plant Pathology 53: 802.

Wardlaw, C.W. 1972. Banana disease including Plantains and Abaca. $2^{\text {nd }} e d$. Longman, London. pp 878Yirgou, D. and J.F. Bradbury. 1968. Bacterial wilt of Enset (Ensete ventricosum) incited by Xanthomonas species. Phytopathology 58:111-112.

Yirgou, D. and Bradbury, J.F. 1974. A note on wilt of banana caused by the enset wilt organism Xanthomonas campestris pv. musacearum. East African Agricultural and Forestry Journal 40(1):111-114. 